J-DEPACE, Volume 3, Nomor 2, Desember 2020, Hal 220-230

Tersedia online di :http://jurnal.lpmiunvic.ac.id/index.php/jpkm

\title{
PENGEMBANGAN APLIKASI PARIWISATA BERBASIS ANDROID DALAM UPAYA PENINGKATAN AKSESIBILITAS UKM (DESA WISATA) KAMPUNG PAM DI KABUPATEN RAJA AMPAT PROVINSI PAPUA BARAT
}

\author{
Marcelinus Petrus Saptono, S.Kom, M.Cs ${ }^{1 *}$, Ery Murniyasih, S.Kom., M.Kom ${ }^{2}$ \\ Luluk Suryani, S.Kom., M.MT ${ }^{3}$, Raditya Faisal W., S.Kom., M.Kom ${ }^{4}$ \\ Program Studi Teknologi Rekayasa Komputer Jaringan, Politeknik Saint Paul Sorong \\ ${ }^{1}$ marcell.poltekstpaul@gmail.com*,2 ery.murniyasih@gmail.com, \\ ${ }^{3}$ luluk.suryani@gmail.com , ${ }^{4}$ waliulu.raditya@gmail.com
}

\begin{abstract}
ABSTRAK
Kabupaten Rajaampat salah satu kepulauan di Provinsi Papua Barat di Indonesia. Wisatawan domestik dan mancanegara yang datang sebelum Covid-19 pada tahun 2019 bisa mencapai 32.000 pengunjung (sumber: kumparan.com). Di masa Pandemic Covid-19 hampir tidak ada sama sekali pengunjung yang datang sehingga sangat berdampak bagi perekonomian UMKM di wilayah Kabupaten Raja Ampat. UMKM tidak efektif lagi melakukan promosi dan publikasi objek wisata dengan cara konvensional, harus ada terobosan baru dengan memanfaatkan teknologi informasi, database maupun smartphone android. Berdasarkan permasalahan tersebut, maka tujuan dari penelitian dan pengabdian kepada masyarakat ini memberikan solusi berupa perancangan dan pembuatan sistem informasi website pariwisata Rajaampat dengan berbasis android. Metode pendekatan pengembangan sistem yang digunakan dalam penelitian ini adalah Object Oriented Analysis and Design (OOAD) dengan Unified Modeling Language (UML) sebagai modelnya. Sistem yang dibuat dibagi menjadi dua bagian, yaitu sistem backend berbasis web dengan PHP dan database MySql, dan aplikasi android berbasis mobile untuk wisatawan. Hasil dari penelitian dan pengabdian kepada masyarakat ini yaitu (1) website gotriprajaampat.com yang dapat diakses melalui website dan smartphone android. (2) publikasi di media cetak Papua Barat Pos, Publikasi media online di website terdepan.co.id, terdepan.co.id/live/ dan (3) publikasi media youtube.
\end{abstract}

Kata kunci: Pariwisata, Rajaampat, Android mobile, UML, OOAD 


\begin{abstract}
Rajaampat Regency is one of the islands in West Papua Province in Indonesia. Domestic and foreign tourists who arrived before Covid-19 in 2019 could reach 32,000 visitors (source: kumparan.com). During the Covid-19 Pandemic there were almost no visitors who came so that it greatly impacted the economy of MSMEs in the Raja Ampat Regency area. UMKM is no longer effective in promoting and publishing tourist objects in conventional ways, there must be a new breakthrough by utilizing information technology, databases and Android smartphones. Based on these problems, the purpose of this research and community service is to provide a solution in the form of designing and making an Android-based Rajaampat tourism website information system. The system development approach method used in this research is Object Oriented Analysis and Design (OOAD) with Unified Modeling Language (UML) as the model. The system created is divided into two parts, namely a web-based backend system with PHP and MySql databases, and a mobile-based android application for tourists. The results of this research and community service are (1) the gotriprajaampat.com website which can be accessed through the website and android smartphone. (2) publications in the print media of Papua Barat Pos, online media publications at the terdepan.co.id website, terdepan.co.id/live/ and (3) the youtube media publication.
\end{abstract}

Keywords: Tourism, Rajaampat, Android mobile, UML, OOAD

\title{
1. PENDAHULUAN
}

Pariwisata Raja Ampat di Papua Barat sudah dikenal dunia dengan pemandangan laut yang eksotik baik dari bentuk, pemandangan bawah laut maupun aneka jenis ikan yang ada di dalamnya. Seiring pariwisatanya dikenal dunia, nyatanya pembangunan pariwisata masih biasa-biasa saja belum menyentuh lapisan masyarakat Raja Ampat. Dampak ekonomi pandemic covid-19 di Kabupaten Raja ampat mengakibatkan tidak ada wisatawan yang datang sehingga tidak ada pendapatan bidang pariwisata tentunya ini menjadi dampak luar biasa kehidupan masyarakat raja ampat yang tergantung dengan kegiatan bisnis dan pariwisata. Akibat ketidakjelasan pandemic covid-19 memberi dampak ekonomi pariwiwata menjadi terpuruk sehingga satu-satunya solusi melakukan transformasi digital di bidang pariwisata dengan menggunakan marketing digital berbasis website.

Berikut gambaran pariwisata dan UKM yang ada di desa wisata kampung PAM Kabupaten raja ampat. 


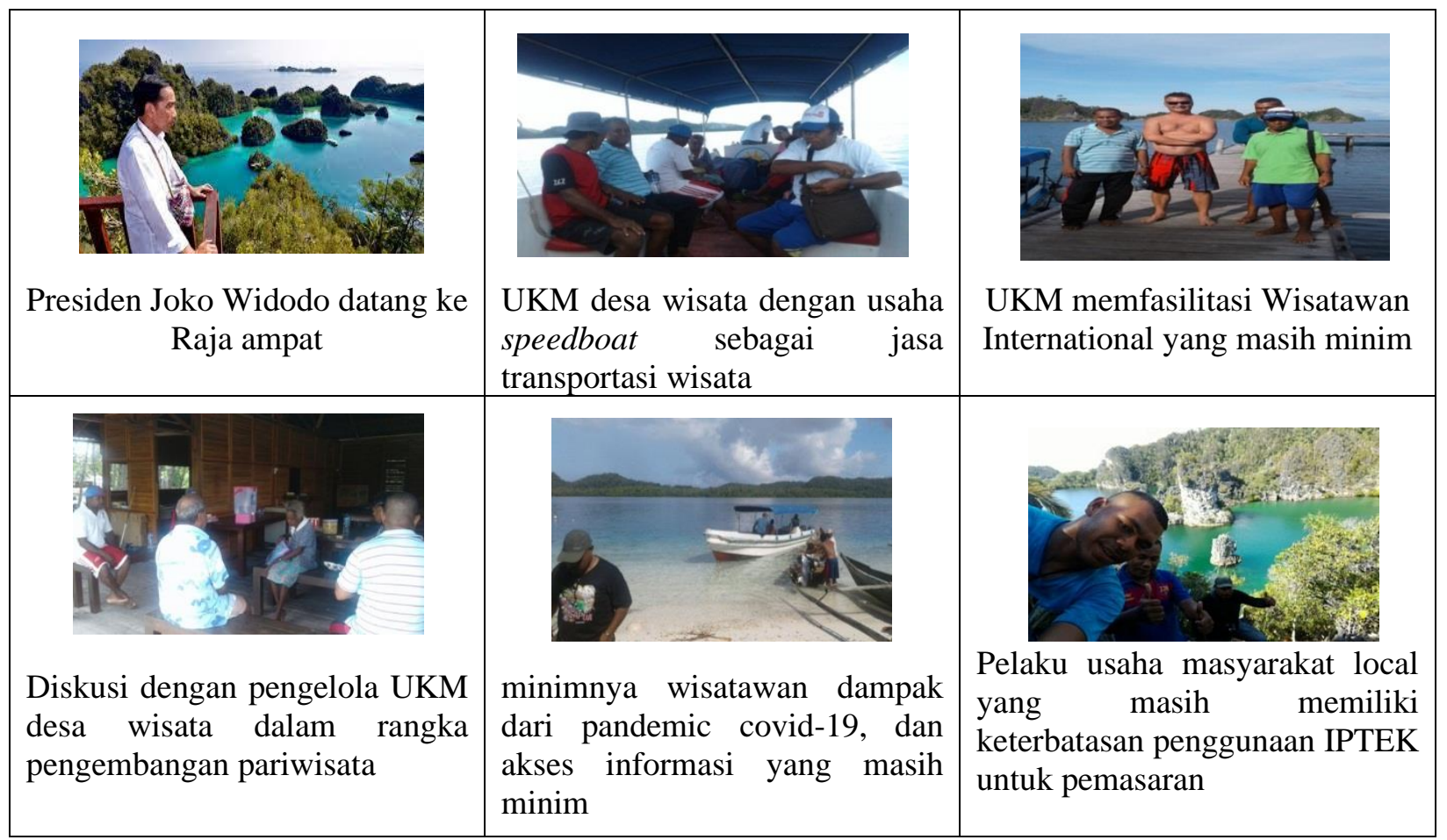

\section{Gambar 1. Profil Kegiatan UKM Desa Wisata Kampung PAM}

GPS (Global Positioning System) adalah sistem untuk menentukan lokasi di permukaan bumi menggunakan sinkronisasi sinyal satelit (Budiawan, 2011). LBS (Location Bases Service) merupakan sebuah service untuk memberikan informasi sesuai lokasi kita berada. LBS (Location Bases Service) memanfaatkan teknologi GPS (Saputra, 2017). Smartphone adalah telepon selular dengan mikroprosesor, memori layar dan modem bawaan (Williams, 2011). Android merupakan mobile Operating System (OS) yang dikembangkan oleh Google yang berbasis pada OS Linux Kernel.

Solusi dari permasalahan diatas adalah dengan dengan membuatkan aplikasi website pariwisata yang mudah diakses secara online berbasis android. Aplikasi Pariwisata Berbasis Android Dalam Upaya Peningkatan Aksesibilitas UKM (Desa Wisata) di Kabupaten Raja Ampat Provinsi Papua Barat dibangun terdiri dari dua bagian, (1) sistem backend berbasis web untuk administrator dan (2) aplikasi android objek wisata berbasis mobile untuk wisatawan dengan menggunakan teknologi seperti: (1) Global Positioning system (GPS), (2) Google Maps Android dan (3) Google maps directions. Aplikasi ini dapat digunakan oleh wisatawan pada smartphone 
bersistem operasi Android dan koneksi internet. Melalui aplikasi ini wisatawan bisa mendapatkan informasi lokasi tempat yang akan dikunjungi, kemudian dapat memperkirakan jarak terdekat dari lokasi tujuan dan sekaligus dapat melihat gambaran dan informasi singkat mengenai lokasi yang menjadi tujuan pengunjung. Aplikasi ini juga mempunyai sistem backend yang berfungsi sebagai media untuk mengelola informasi pariwisata oleh UKM kampung PAM Kabupaten Raja Ampat, Beberapa kelebihan yang dimiliki oleh aplikasi yang dibangun adalah: 1) Tersedianya gambaran geografis lokasi objek wisata di Kabupaten Raja Ampat. 2) Bisa digunakan di mana saja dan kapan saja selagi ada koneksi internet. 3) Aplikasi ini tidak hanya menampilkan informasi kepariwisataan tetapi juga menampilkan informasi seperti: (1) paket wisata; (2) private tour; (3) services; (4) Resort; (5) Gallery; dan (6) store dan informasi penting terkait wisata lainnya. Sistem dapat diakses melalui website dan smartphone android. Sedangkan model yang digunakan untuk dengan diagram Unified Modeling Language (UML), yaitu (1) use case diagram, (2) sequence diagram, (3) class diagram. Aplikasi yang dihasilkan akan dijadikan sebagai media informasi dan promosi bagi wisatawan

\section{MASALAH}

UMKM (Usaha Mikro Kecil dan Menengah) Pariwisata Rajaampat memiliki potensi yang luar biasa, selain menawarkan spot-spot wisata yang indah dan menarik, UMKM dapat menyewakan homestay, penginapan, dan resort, diving, menyewakan speedboat dan menjual produk-produk local yang dihasilkan oleh masyarakat local. Merosotnya industri pariwisata akibat virus covid-19 sangat dirasakan oleh masyarkat Kabupaten Rajaampat. Bahkan Pemerintah Indonesia sendiri mengakui sektor pariwisata lumpuh akibat pandemi Covid-19. Kondisi pariwisata selama pandemi Covid-19 cukup parah, tidak ada wisatawan yang datang, maupun tamu yang menginap di homestay, penginapan maupun resort. Bulan agustus 2020 tempat pariwisata rajaampat mulai dibuka, membawa harapan baru, penerapan protokol kesehatan dan pembatasan transportasi maupun jumlah penumpang masih belum membawa dampak positif bagi pariwisata karena masih sedikitnya wisawatan domestik yang datang. Kasus virus corona di Indonesia terkonfirmasi masih terus meningkat, para pelaku bisnis dan UMKM harus tetap bertahan sampai akhir selesainya pandemi virus covid-19. 
Dari masalah tersebut maka diperlukan strategi yang tepat untuk memulihkan dan menggerakkan roda perekonomian khususnya sektor pariwisata, antara lain: (1) membuat branding strategi baru misalnya live new normal, (2) menggunakan media digital seperti website, aplikasi android dan media sosial untuk melakukan promosi. (3) Melakukan promosi safety and healthy of tourism ke turis internasional. (4) Menerapkan protokol kesehatan yang bersifat wajib atau mandatory dan menjaga kebersihan penginapan, homestay dan lokasi wisata.

\section{METODE PELAKSANAAN}

Pendekatan pengembangan sistem yang digunakan adalah Object Oriented Analysis and Design (OOAD). Ada tiga buah diagram Unified Modeling Language (UML) yang digunakan yaitu: (1) use case diagram, (2) sequence diagram, (3) class diagram. Sedangkan untuk sosialiasasi penggunaan aplikasi dilakukan dengan pelatihan semacam in-house training.

\subsection{Analisa dan Perancangan Sistem}

Sistem yang dibangun terdiri dari dua bagian, (1) sistem backend berbasis web untuk administrator dan (2) aplikasi android objek wisata berbasis mobile untuk wisatawan. Pada tahap ini, baik untuk aplikasi android navigasi maupun sistem backend dilakukan: (1) analisa sistem yang sedang berjalan; (2) analisa sistem usulan; dan (3) perancangan sistem. Analisa sistem yang sedang berjalan dilakukan dengan cara menganilisis hasil wawancara dan observasi serta dokumendokumen yang didapat dari tahap perencanaan. Sedangkan pada tahap analisa sistem usulan dibuat: (1) arsitektur sistem; (2) analisa kebutuhan fungsional sistem; dan (3) aliran data yang terdapat pada sistem. Kebutuhan fungsional dan aliran data secara berturut-turut digambarkan menggunakan usecase diagram dan sequence diagram. Pada tahap perancangan sistem dilakukan pembuatan class diagram, perancangan basis data, perancangan struktur menu serta perancangan antarmuka.

\subsection{Peralatan Hardware dan Softwareyang diperlukan}

Berikut merupakan lingkungan implementasi pada penelitian ini.

\section{a) Aplikasi berbasis mobile Android}

(a) Perangkat keras

Smartphone: Asus-Z007 
(b) Perangkat lunak

MIT App Inventor 2, Sistem operasi: Android KitKat 4.4.2, android studio, framework laravel, atom text editor, Nginx web server.

\section{b) Sistem backend berbasis website}

(a) Perangkat keras

Adapun perangkat keras dalam implementasi aplikasi ini yaitu:

a. Komputer dengan resolusi 1366 x 768, Memori 1 GB RAM dan harddisk 80 GB, Prosesor Intel® Core 2 Duo.

b. Android v2.3 (Gingerbread), CPU 1 GHz Cortex-A5, GPU Adreno 200, Display dengan resolusi $360 \times 720$ pixels

(b) Perangkat lunak

a. Sistem operasi: Windows 7 ,Browser: Mozilla Firefox, Bahasa pemrograman: PHP

b. Framework: Bootstrap, Database: MySql, Adobe Photoshop CS4, Notepad++, PhpMyAdmin 3.2.4, Web Service, Xampp win64

Pengujian aplikasi dilakukan dengan menggunakan metode black box dan User Acceptance Test (UAT). Ada dua buah skenario uji yang digunakan untuk masing-masing pengujian. Skenario pertama adalah untuk menguji system backend berbasis website dan skenario kedua adalah untuk menguji aplikasi berbasis mobile.

\subsection{Arsitektur Sistem}

Arsitektur sistem yang dibangun dapat dilihat pada Gambar 2. Pada gambar tersebut wisatawan mengakses aplikasi melalui smartphone, sedangkan administrator mengakses sistem backend berbasis website melalui computer/laptop. Jika wisatawan membutuhkan data dan informasi mengenai objek wisata maka aplikasi akan memanggil data tersebut dari database di server sistem dan menampilkannya pada aplikasi mobile. Apabila wisatawan ingin melihat informasi obyek wisata dan peta navigasi, maka aplikasi akan memanggil koordinat objek wisata dari database di server dan mengambil koordinat wisatawan melalui GPS yang ada di smartphone. Setelah itu, menggunakan Google Maps Directions API, aplikasi membuat peta rute dari koordinat lokasi wisatawan ke koordinat objek wisata dan ditampilkan ke smartphone wisatawan. Arsitektur system ditunjukkan pada Gambar 2 berikut: 


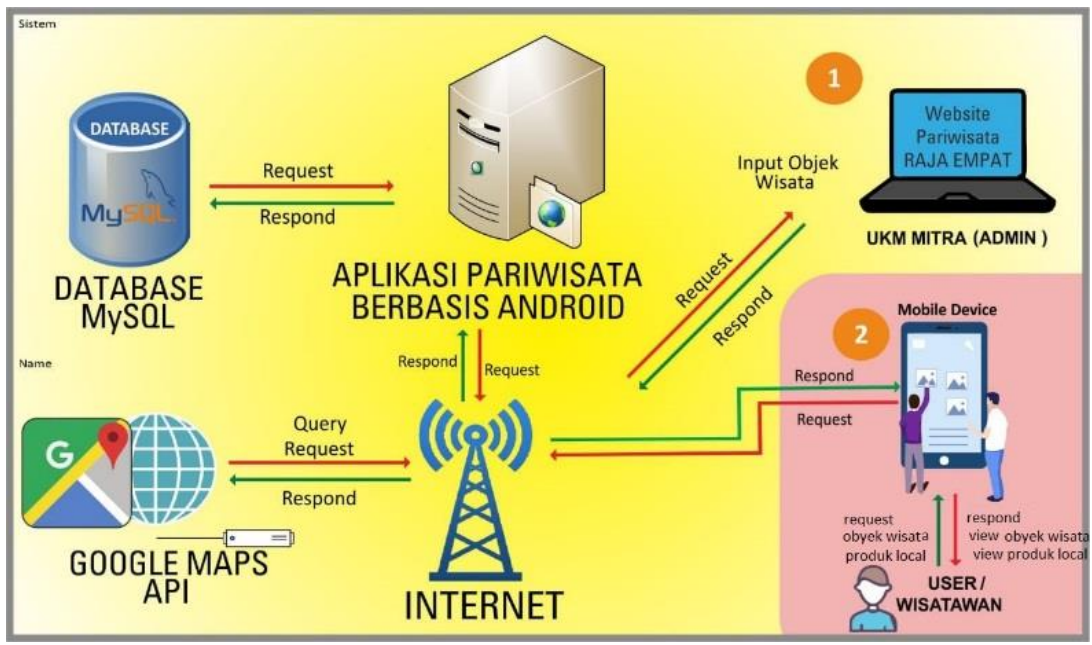

Gambar 2. Arsitektur Sistem

\subsection{Gambaran Teknologi dan Desain System Mobile}

Gambaran tampilan aplikasi obyek wisata berbasis android untuk wisatawan seperti tampak gambar berikut, user dapat mengakses informasi melaui website gotriprajaampat.com dan dapat mengakses dengan smartphone android. Aplikasi dapat di install melalui google play store terlebih dahulu. Berikut gambaran sistemnya.

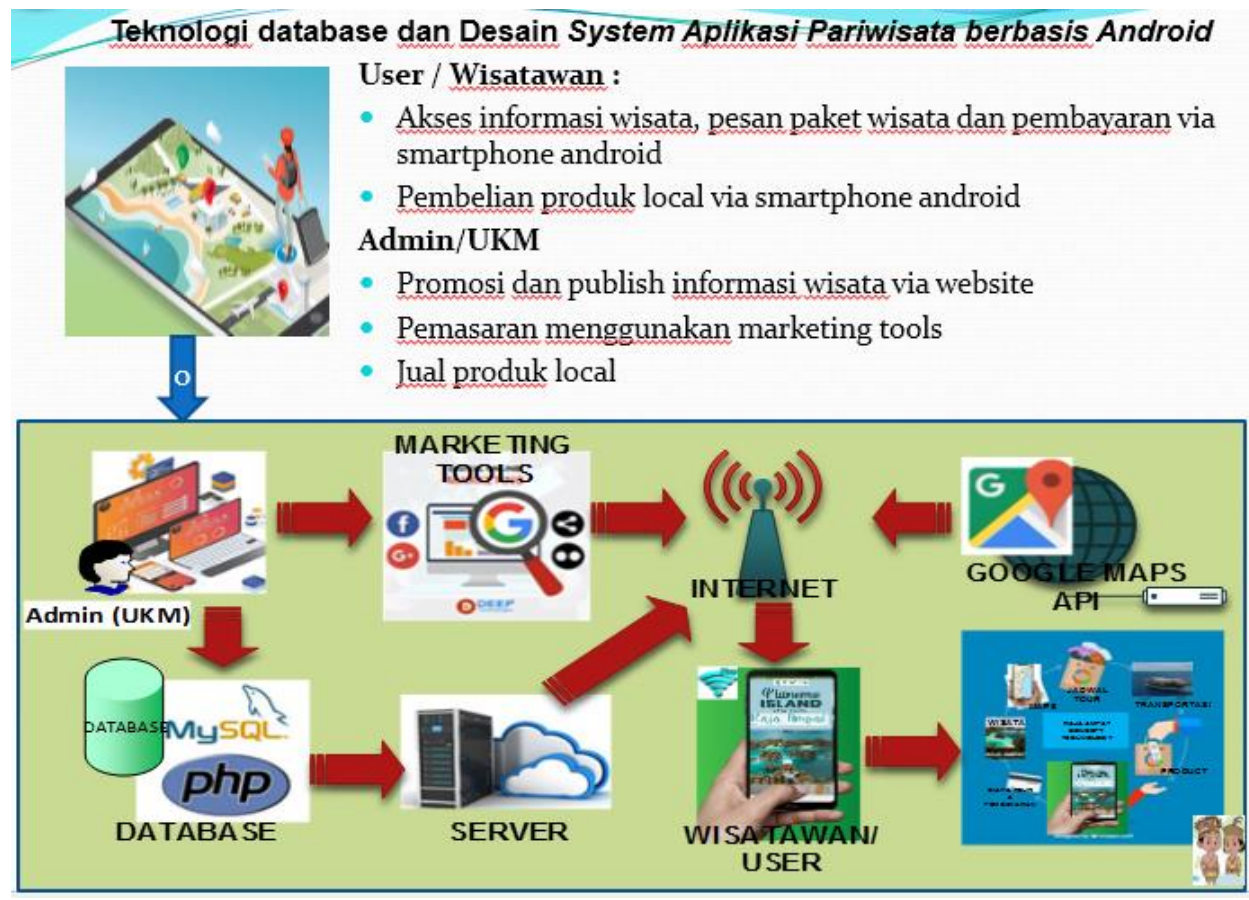

Gambar 3. Gambaran Desain system informasi Pariwisata 


\section{HASIL DAN PEMBAHASAN}

Adapun hasil dan pembahasan dari kegiatan pengabdian kepada masyarakat sebagai bentuk implementasi Tri Dharma Perguruan Tinggi untuk membantu meningkatkan perekonomian masyarakat UKM Kabupaten Rajaampat adalah sebgai berikut:

\subsection{Pembuatan Sistem dan Pelatihan Penggunaan Website UKM}

Hasil dari kegiatan PKM ini adalah pembuatan sistem informasi pariwisata website berbasis mobile android yang bisa diakses secara online di Gotriprajaampat.com, berikut gambaran sistem dan kegiatan pelatihan untuk UKM.

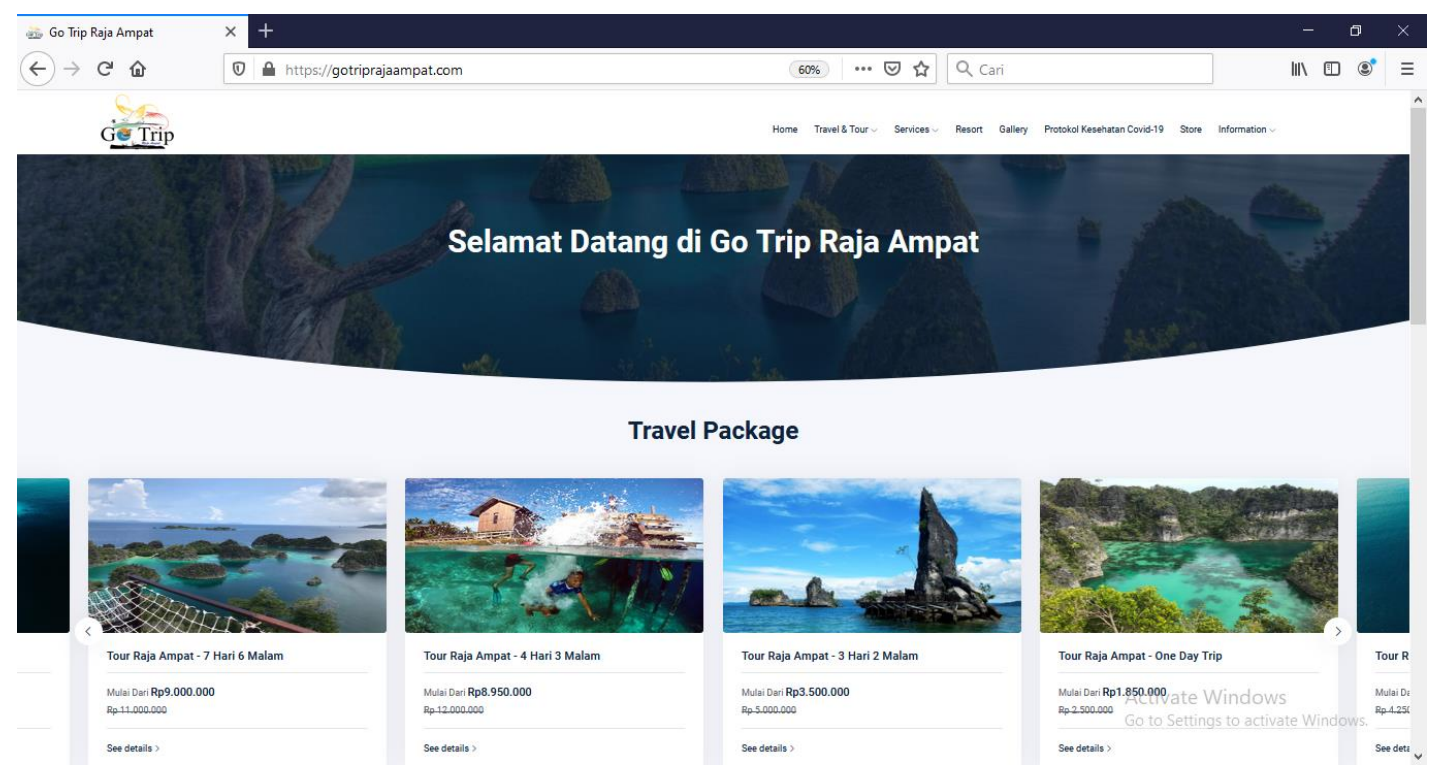

Gambar 4. Halaman Utama Website Pariwisata Raja Ampat 
Marcelinus Petrus Saptono, dkk Pengembangan Aplikasi Pariwisata Berbasis Android Dalam Upaya Peningkatan Aksesibilitas UKM (Desa Wisata) Kampung Pam Di Kabupaten Raja Ampat Provinsi Papua Barat

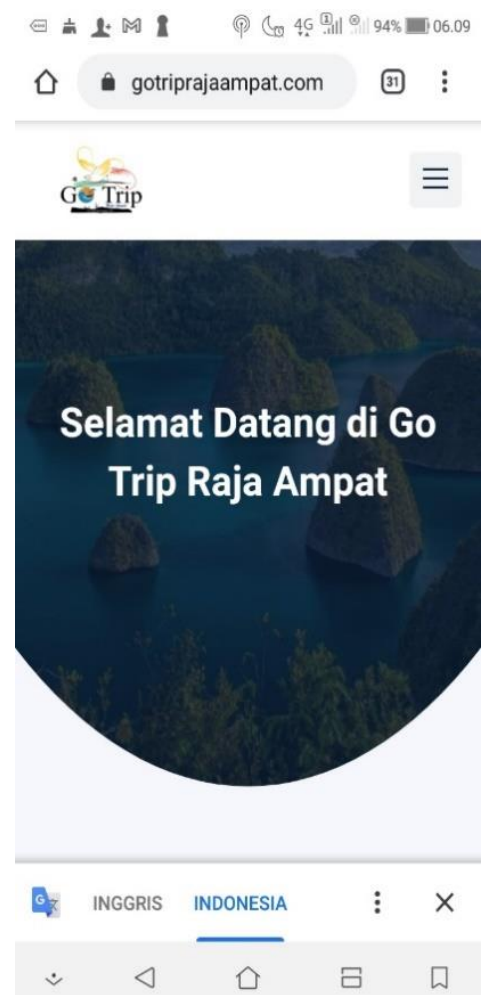

Halaman Utama di Android

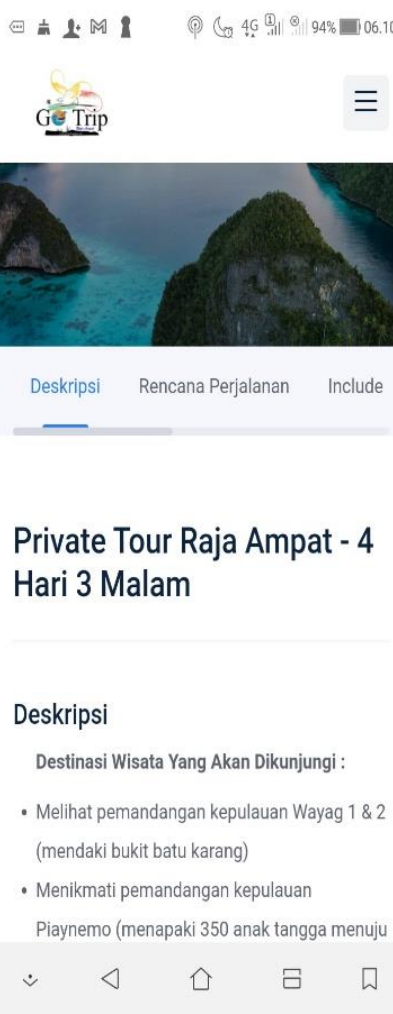

Halaman Paket Travel di Android

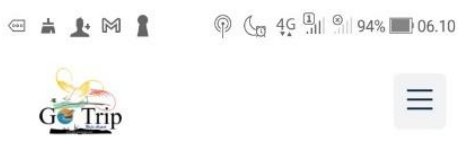

Peta Lokasi

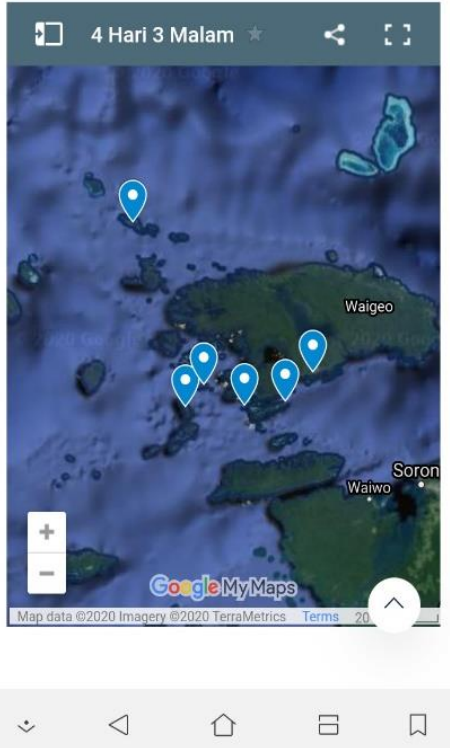

Peta Lokasi wisata di Android

Gambar 5. Halaman Paket Wisata di Smartphone Android

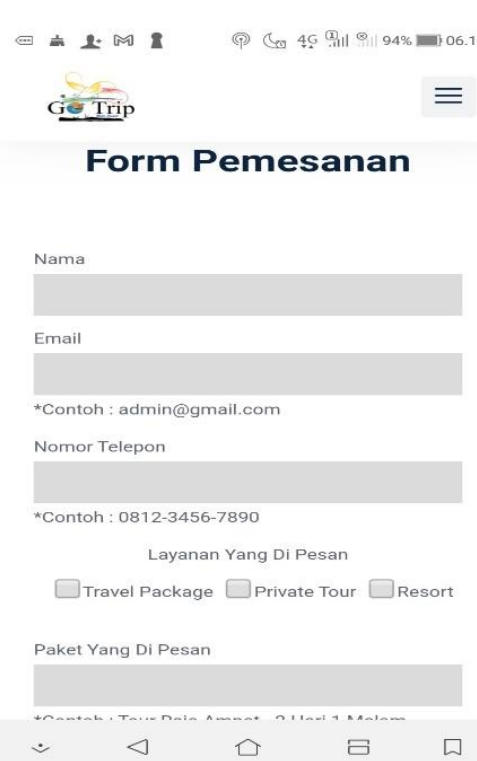

Halaman Form Pemesanan di Android

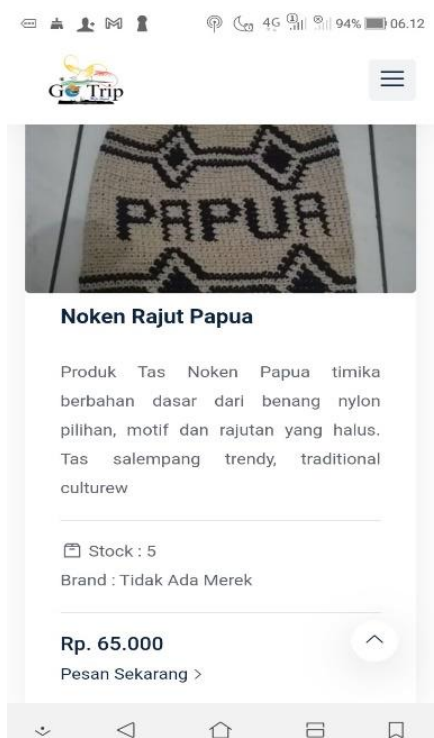

Halaman Store di Android

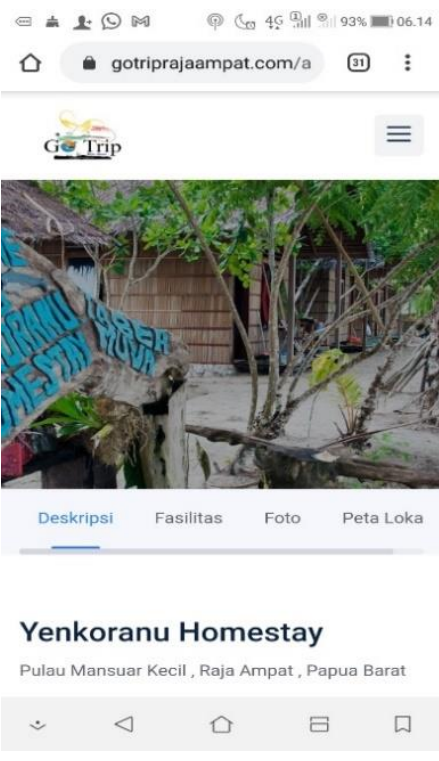

Halaman Resort di Android

Gambar 6. Halaman Store dan Resort di Smartphone Android 


\section{Pelatihan Penggunaan Website}

Dalam pelatihan ini peserta diajarkan bagaimana mengoperasikan website, malakukan input-input data ke dalam website, dan melakukan publikasi ke media website dan media sosial. Pelaksanaan pelatihan ini dilaksanakan pada tanggal 29 November 2020 hingga 2 Desember 2020 di kelurahan Bonkawir Kabupaten Rajaampat. Peserta dari kegiatan ini adalah pelaku UKM kurang lebih diikuti 10 orang dengan tetap menerapkan protokol kesehatan covid-19.

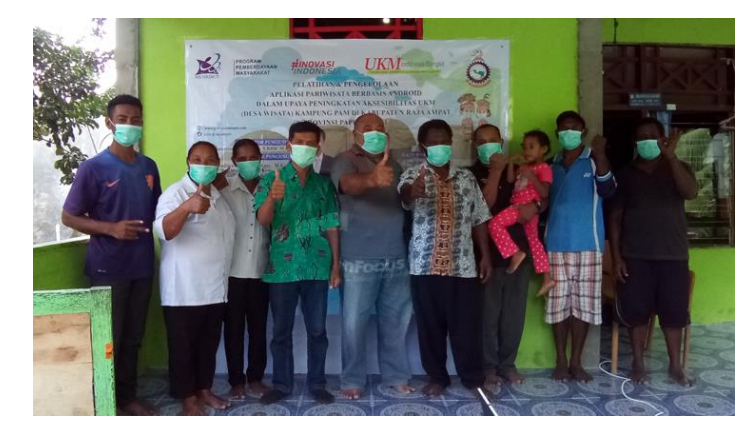

Tim PKM Politeknik Saint Paul Sorong bersama Kelompok UKM Farsaso Ansansonem dan Pegawai Keluarahan Bonkawir Kabupaten Raja Ampat

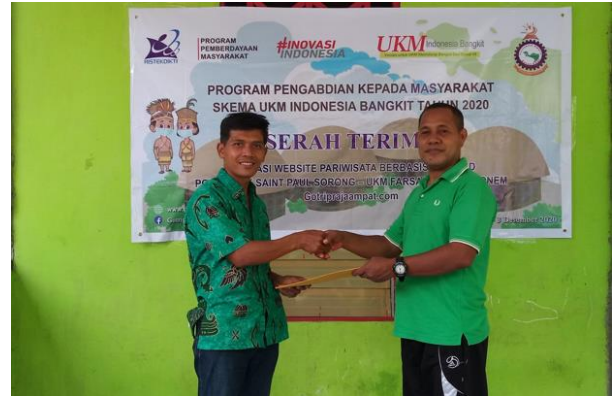

Penyerahan Aplikasi Website Pariwisata dari kepada Ketua UKM Franklin Dimara S.Pd.

\section{Gambar 7. Dokumentasi Kegiatan PKM}

\subsection{Hasil Luaran kegiatan PKM}

Publikasi hasil luaran dari kegiatan pengabdian kepada masyarakat ini adalah dipublikasikan di media cetak Papua barat pos, publikasi di media online terdepan.co.id dan publikasi di media youtube tedepan tv dan jurnal pengabdian masyarakat.

\section{KESIMPULAN}

Kegiatan ini bekerja sama dengan Lembaga Penelitian Dan Pengabdian Masyarakat (LPPM) di Perguruan Tinggi Politeknik Saint Paul. Pelaksanaan kegiatan dan pelatihan dilaksanakan dengan UKM Farsaso Ansansonem bersama warga kampung PAM di Kelurahan Bonkawir yang telah terlaksana dengan baik. Adapun hasil yang di dapat setelah adanya kegiatan ini adalah UKM mempunyai website gotriprajaampat.com untuk promosi-promosi melalui website tersebut seperti objek-objek wisata, usaha-usaha penginapan, homestay dan resort, diving, speedboat dan produk- 
produk lokal yang dimiliki oleh masyarakat. Peserta pelatihan juga mempunyai bekal untuk mempublikasikan ke media sosial ataupun memasarkan produknya melalui media digital smartphone android.

\section{UCAPAN TERIMA KASIH}

Kegiatan pengabdian kepada masyarakat ini terlaksana berkat dukungan Kementrian Riset dan Teknologi/Badan Riset dan Inovasi Nasional yang telah mendanai kegiatan program Pengabdian Kepada Masyarakat Skema UKM Indonesia bangkit tahun 2020.

\section{DAFTAR PUSTAKA}

Budiawan, Tiyo. 2011. Mobile Tracking GPS (Global Positioning System) melelui sms (Short Message Service). Universitas Diponegoro.

Saputra, Ishak. U. 2017. Pengembangan Aplikasi Location Based Service Pariwisata Berbasis Android studi kasus Kabupaten Toraja Utara. Universitas Sam Ratulangi.

Williams, B.K and Sawyer, S.C. 2011. " Using Information Technology: A Practical Introduction to Computer \& Communications. (9th edition)". New York: McGraw-Hill.

https://kumparan.com/balleonews/kunjungan-wisatawan-ke-raja-ampat-meningkat-sepanjang2019-1sYtuPYAiGu/full, diakses tanggal 04 Desember 2020. 